\title{
Role of Selected Agroforestry Tree Species in Promoting Rural Livelihoods Diversification in the Savannah Parklands of North- Western Katsina State, Nigeria.
}

\author{
Nuraddeen Abubakar Maiwada \\ Department of Geography, Umaru Musa Yar'adua University. PMB 2218, Katsina, Nigeria.
}

\begin{abstract}
This study investigates the role of the six selected agroforestry tree species and how they promote livelihoods diversification among 340 smallholders living in 18 rural communities in North-Western Katsina State, Nigeria. It went further to argue that households in the area will go on to modify their livelihood strategies in response to the selected trees' use and management. Modest empirical research has been conducted in the area to investigate this claim so as to extend existing research focus on livelihoods diversification. Methodologically, the study utilized approaches grounded within modified sustainable livelihood framework to gather and analyze socio-economic data with a view to critically evaluate the households' influence on the fortunes of these trees. Results of the chi-square test suggest that these selected trees found in agroforestry systems contribute significantly to livelihoods diversification as well as serve to diversify income sources among the rural communities living within the study area through income sources like sales of fuelwood, traditional medicines, fruits, crafts and honey. This represent a kind of 'productive bricolage' survival strategy these rural households adopt in order to diversify incomes or combining reliance on multiple sources of income to improve livelihoods for many of the smallholders.
\end{abstract}

Key Words: livelihoods, agroforestry, communities, diversification, bricolage, income.

\section{Introduction}

Livelihoods comprise the capabilities and material and social assets necessary for a means of living (Chambers and Conway, 1992 in Agrawal and Perrin, 2008). There are different livelihood practices in the drylands most of whom depend on the natural environment. These natural resource based livelihoods including agriculture depend on the land for their survival. The most prominent livelihood activity in these areas is associated with agriculture and livestock rearing that include sedentary farming, transhumance, and normadic and semi-normadic pastoralism. Chianu et al (2008) reported Ellis (1999) who justify that in the developing world particularly those countries having widespread hunger, $70 \%$ of the poor people living in rural areas obtain their livelihoods from agriculture. These agriculture based livelihoods increasingly transform and change into what is known as livelihoods diversification. Murray, (2001) reported (Bryceson, 1999) in buttressing the point that in sub-Saharan Africa in 1980s, $40 \%$ of the rural household income comes from non-farm enterprises which grew to $60-80 \%$ in the late 1990s showing significant increase in de-agrarianization among households. These diversified livelihood means are non-farm based and are a form of survival strategy adopted by the people for the diversification of their income sources (Nowrotzki et al, 2012; Wang et al. 2011; Nelson et al. 2010; Mortimore and Manvell 2006; Mortimore and Adams, 2001). A good number of these diversified non-farm livelihoods in drylands are natural resource based associated in one way or the other with plant or tree resources.

The dependence on tree products by the rural dwellers is seen as a form of livelihood diversification mechanism to sustain or revamp income generation through the harvesting of wood for selling as firewood as well as non-timber forest products (NTFPs) like fruits, leaves, and seeds. CGIAR, (2011) buttressed this point by revealing from a survey of 9000 households in some poor rural communities that $20-25 \%$ of their annual income is contributed by forest products. Chigwenya and Chirisa (2007) also argued that of the more than 1.2 billion poor people in the world $90 \%$ of them rely on forest products for earning livelihoods.

The study located in North-Western Katsina State, Nigeria deals with six selected agroforestry tree species which include Anogeissus leiocarpus (DC.) Guill. \& Perr., Balanites aegyptiaca (L.) Delile, Faidherbia albida (Delile) A. Chev., Khaya senegalensis (Desr.) A. Juss., Parkia biglobosa (Jacq.) R. Br. Ex Don., and Vitellaria paradoxa C.F. Gaertn. It is aimed at measuring the relative contributions of these selected tree species in sustaining livelihood portfolios in the study area. Their prioritization is based on the fact that most of them have high potentials for agro-forestry development including a diversity of uses and widespread occurrence in many localities despite the existence of human agricultural activities. 


\section{Location of the Study Area}

\section{Materials and Methods}

The study location comprise Batsari, Kurfi and Jibia Local Government Areas (figure 1) that spans an agro-ecological landscape with a range of site types that fall within latitudes $12^{\circ} 30^{\prime}$ North and $13^{\circ} 06^{\prime}$ North of the equator and longitudes $7^{0} 15^{\prime}$ East and $7^{0} 30^{\prime}$ East of the Greenwich Meridian. It is within these three localities that the actual study sites or communities were situated (figure 2). This Sudano-Sahelian area lying in the north-western part of Katsina State in the extreme north of Nigeria extends for some $80 \mathrm{~km}$ from west to east and $100 \mathrm{~km}$ from north to south. The cumulative land area of this sampled area is $2,716 \mathrm{~km}^{2}$ representing about $10 \%$ of the state's total land mass. Its combined population is about 496,307 people (NPC, 2006). The proximity of the area to the Sahara desert to the north makes it to have biophysical constraints like low and unpredictable rainfall.

\section{Sampling Technique}

A multi-stage sampling design has been employed here. The first stage was the selection of the eighteen rural communities using stratified random sampling method, ensuring that samples spread over the three administrative units. Here the three administrative units have served as the strata and within each stratum random sampling took place so that each region was accorded certain number of communities based on its proportional geographical area.

The second stage involved households sampling which was undertaken through random sampling method in a way that ensured that as much as possible a fair representation of the households was achieved. Here households were selected from each of the selected rural communities proportionally. In all three hundred and forty five households from the eighteen rural communities were selected thus Batsari has 143, Kurfi has 145 while Jibia has 57 respondents. Three focus groups for collecting community level data were also selected purposively in the study area considering budget constraints and the difficulties encountered in obtaining participants. The study area is also not very diverse in terms of its culture and biogeography hence the limited number of the focus groups selected.

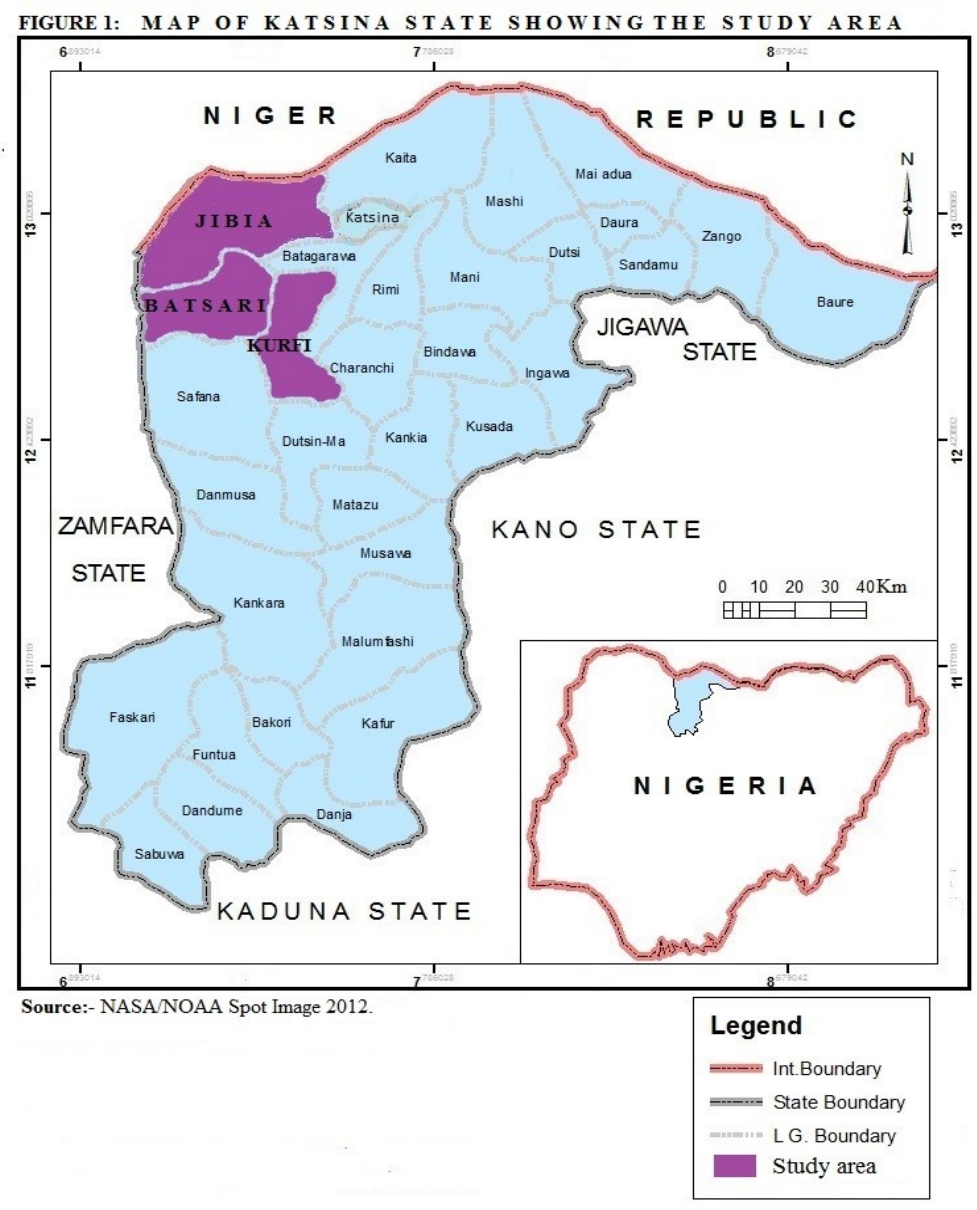




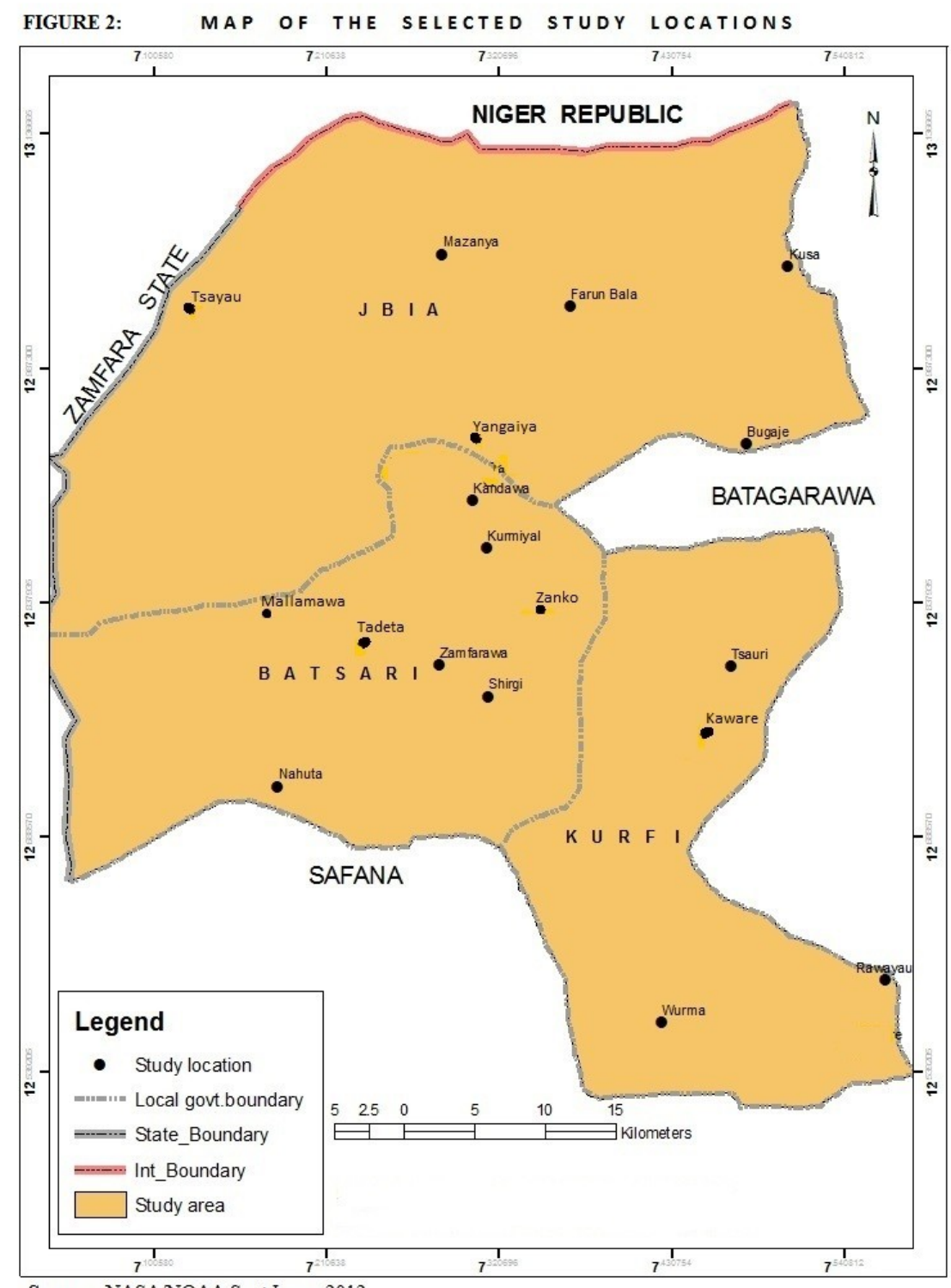

Source:- NASA/NOAA Spot Image 2012.

\section{Data Collection and Analysis}

Data collection was also conducted in two stages. The first stage was the questionnaire administration whereby every one of the household was visited and in each the household head (man or woman) or their representative formed the basis for the questionnaire interview by the research assistants. In this way all the households were covered and the questions were interpreted in the local language by the assistants when it was deemed necessary.

The second stage involved three focus group discussions in three chosen villages of Tsauri, Mazanya and Mallamawa of ten participants each to complement the household level data collected through the questionnaire. The participants were composed of specialized people that include tree users and experts such as, fuel wood sellers, herbalists, and some community/village elders who are believed to be knowledgeable about the six selected economic trees.

Three hundred and forty respondent's data was used in the analysis after data scrutiny using crosstabulations and chi-square analysis on SPSS to see whether and how a vector of independent variable (selected economic tree use variables) will account for the variability of a response dependent variable (rural livelihood variables). 


\section{Results and Discussion}

Table 1 portrays the average percent distribution of respondent's major income sources in the study area which also depicts their means of livelihoods. It shows the major household's financial capital inflows in the localities derived from sales associated with crop, tree, livestock, and off-farm enterprises. Rank 1 category shows that the major source of livelihood to the respondents is through the sales of farm products where both food and cash crops like millet, sorghum, beans, sweet potato and groundnuts were sold to get some cash income despite the subsistence condition of many farmers in the area. It will be noted that farming is less important in Jibia Locality than it is in Kurfi and Batsari localities obviously due to the hasher climatic conditions there. The other major source of livelihood apart from farming is from the sales of livestock and livestock products like milk and meat.

Livelihoods associated with the selected trees products are very important. These include sale of firewood particularly in Batsari locality probably owing to its close proximity to a forest reserve in the south west of the study area. Traditional medicines are also sold from the parts of some of the selected trees like barks, roots and leaves. Business income is another livelihood activity in the area especially in Jibia locality that also shares an international border with Niger Republic to the north. This together with the drier climatic conditions makes people go into more business enterprises there where farming is not so lucrative compared to other localities.

In rank 2 category, the sales of the aforementioned also appear and this time fruit sale comes around. This shows their importance in the study area. Rank 3 categories include mostly off-farm enterprises like some of the respondents receiving cash remittances from brothers and other close associates as well as migrant labor particularly in Jibia locality, others were wage incomes like teaching and poultry sales. Another tree product enterprise is the sale of honey but this is not very important as it was only found in Batsari locality.

Table 1: Household's Major Sources of Cash Income (Livelihoods)

\begin{tabular}{|c|c|c|c|c|c|c|c|c|}
\hline \multirow[t]{2}{*}{ Ranking Order } & \multirow[t]{2}{*}{ Sources of Cash Income } & \multicolumn{2}{|c|}{ Batsari } & \multicolumn{2}{|c|}{ Jibia } & \multicolumn{2}{|c|}{ Kurfi } & \multirow{2}{*}{$\begin{array}{l}\text { Average } \\
\text { Percent }\end{array}$} \\
\hline & & Freq & $\%$ & Freq & $\%$ & Freq & $\%$ & \\
\hline \multirow[t]{7}{*}{ Rank 1} & Sale of food crops & 41 & 29.7 & 13 & 22.8 & 55 & 37.9 & 30.1 \\
\hline & Sale of Firewood & 19 & 13.8 & 9 & 15.8 & 17 & 11.7 & 13.8 \\
\hline & Sale of Livestock & 42 & 30.4 & 13 & 22.8 & 40 & 27.6 & 26.9 \\
\hline & Sale of Cash Crops & 17 & 12.3 & 5 & 8.8 & 19 & 13.1 & 11.4 \\
\hline & Business Income & 11 & 8.0 & 13 & 22.8 & 9 & 6.2 & 12.3 \\
\hline & Traditional Medicines & 8 & 5.8 & 4 & 7.0 & 5 & 3.5 & 5.4 \\
\hline & Total & 138 & 100 & 57 & 100 & 145 & 100 & 100 \\
\hline \multirow{8}{*}{ Rank 2} & Sale of Fruits & 20 & 14.5 & 2 & 3.5 & 17 & 11.7 & 9.9 \\
\hline & Traditional Medicines & 14 & 10.1 & 8 & 14.0 & 13 & 9.0 & 11.0 \\
\hline & Sale of Crafts & 14 & 10.1 & 6 & 10.5 & 17 & 11.7 & 10.8 \\
\hline & Business Income & 26 & 18.9 & 21 & 36.9 & 29 & 20.0 & 25.3 \\
\hline & Sale of Firewood & 21 & 15.2 & 9 & 15.8 & 23 & 15.9 & 15.6 \\
\hline & Sale of Food Crops & 20 & 14.5 & 5 & 8.8 & 21 & 14.5 & 12.6 \\
\hline & Sale of Livestock & 23 & 16.7 & 6 & 10.5 & 25 & 17.2 & 14.8 \\
\hline & Total & 138 & 100 & 57 & 100 & 145 & 100 & 100 \\
\hline \multirow[t]{8}{*}{ Rank 3} & Cash Remittances & 28 & 20.3 & 11 & 19.3 & 33 & 22.8 & 20.8 \\
\hline & Wage Income & 19 & 13.8 & 9 & 15.8 & 27 & 18.6 & 16.1 \\
\hline & Sale of Honey & 5 & 3.6 & 0 & 0 & 0 & 0 & 1.2 \\
\hline & Sale of Poultry & 25 & 18.1 & 7 & 12.3 & 31 & 21.4 & 17.3 \\
\hline & Sale of Livestock & 31 & 22.5 & 19 & 33.3 & 19 & 13.1 & 23.0 \\
\hline & Sale of Firewood & 30 & 21.7 & 8 & 14.0 & 35 & 24.1 & 19.9 \\
\hline & Migrant Labor & 0 & 0 & 3 & 5.3 & 0 & 0 & 1.7 \\
\hline & Total & 138 & 100 & 57 & 100 & 145 & 100 & 100 \\
\hline
\end{tabular}

Source: Field Work, 2012

A point worth noting is that many households have significant off-farm income generating activities in the study area suggesting some level of livelihood diversification away from agriculture. While crop sales remain the most important enterprise, others like selected trees and off-farm or non-agricultural enterprises are significant and these represent a kind of 'productive bricolage' survival strategy these rural households adopt in order to diversify incomes or combining reliance on multiple sources of income to improve livelihoods.

This corroborates findings from studies in Fandou Beri village in South-Western Niger (Batterbury, 2001), Romwe and Mutanga villages in Chivi District of Masvingo Province in South-Eastern Zimbabwe (Campbell et al, 2002) and 8 rural communities in five districts in northern Ghana (Marchetta, 2011) where it was revealed in the households there that wide-ranging livelihood portfolios exist to increase income sources and make life better.

Result of the chi-square test indicated a significant difference between the selected trees' use and management variables and its influence on household livelihood variables. We therefore reject the $\mathrm{H}_{0}$ and accept 
$\mathrm{H}_{\mathrm{A}}$ hypothesis which says that these livelihood variables depend on the selected trees' use and management since all the p-values of the livelihood variables of the chi-square test are less than the significance level of 0.05 at $95 \%$ level of significance and 1 degree of freedom.

\section{Conclusion}

The six selected agroforestry tree species continue to contribute significantly to rural livelihoods diversification in the rural communities living within the predominantly farmed parklands of the study area through their use values. This is in spite of the dominance of agriculture in the rural economy of the area. A livelihoods portfolio including selected trees enterprises is the panacea to rural poverty especially as agriculture in these areas depends largely if not completely on vagaries of the climate particularly rainfall. For a long time to come, these trees which are protected by the smallholders principally in an on-farm situation will occupy an important position in the income enhancement of the communities living in these areas.

\section{References}

[1]. Agrawal, A., and Perrin, N. (2008). Climate Adaptation, Local Institutions, and Rural Livelihoods. IFRI Working Paper W081 -6, 350-367 http:// sitemaker.Umich.edu/ifri/files/w0816.agrawal perrin .pdf.

[2]. Batterbury, S. (2001). Landscapes of Diversity: A Local Political Ecology of LivelihoodsDiversification in South-Western Niger. Journal of Cultural geographies, 8 (4):437-464.doi: 1177/096746080100800404

[3]. Campbell, B.M., Jeffrey, S., Kozanayi, W., Luckert, M., Mutamba, M., and Zinda, C., (2002).

[4]. Household Livelihoods in Semi-Arid Regions. Options and Constraints, 153. Published by Center for International Forestry Research (CIFOR), Bogor, Indonesia.

[5]. Chianu, J.N., Ajani, O.I.Y and Chianu, J.N. (2008). Livelihoods and Rural Wealth Distribution Among Farm Households in Western Kenya: Implications for Rural Development, Poverty

[6]. Alleviation, intervention and Peace. African Journal of Agricultural Research, 3 (7): 455- 464. Academic Journals. http://www.academicjournals.org/AJAR

[7]. Chigwenya, A. and Chirisa, I. (2007). Structures without Processes: An Analysis of the Institutional Deficiencies in Community Based Forest Resource Management in Seke Resettlement Scheme. Journal of Sustainable Development in Africa, 9, No.4, 2007).Fayetteville, State University, Fayetteville, North Carolina, U.S.A.http://hdl.handle.net/10646/588

[8]. Consultative Group on International Agricultural Research. (2011) Forests, Trees and Agroforestry: Livelihoods, Landscape and Governance. CGIAR Research Program6, Proposal.2011.

[9]. Marchetta, F. (2011). On the Move Livelihood Strategies in Northern Ghana. Document de travail de la serie. CERDI Etudes et Document, 3-31, E 2011.13. htt://www.cerdi.org/ed

[10]. Mortimore, M.J., and Adams, W.M. (2001). Farmer Adaptation, Change and 'Crisis' in the Sahel. Global Environmental Change, 11: 49-57. www.elsevier.com/locate/gloenvcha

[11]. Mortimore, M. and Manvell, A. (2006). Climate Change: Enhancing Adaptive Capacity. Green Ink Limited, UK.www.fanrpan.org/documents/d000239/climate change NRSP Mar2006.pdf

[12]. Murry, C. (2001). Livelihood Research: Some Conceptual and Methodological Issues. Chronic Poverty Research Centre. Background Papers 5.

[13]. National Population Commission (2006). Population and Housing 2006 Census (Nigeria): Final Results Gazetteer.

[14]. Nelson V., Morton J., Chancellor T., Burt, P., Barry, P. (2010). Climate Change, Agricultural Adaptation and Fair Trade. Identifying the Challenges and Opportunities. Natural Resource Institute Working Paper Series, No.1. University of Greenwich

[15]. Nowrotzki, R.J., Hunter, L.M., and Dickinson, T.W. (2012). Rural Livelihoods and Access to

[16]. Natural Capital: Differences between migrants and Non-Migrants in Madagascar. Demographic Research, 26, article 24, 661-700. doi: 10.4054/DemRes.2012.26.24

[17]. Wang, C., Yang, Y., and Zhang, Y. (2011). Economic Development, Rural Livelihoods and Ecological Restoration: Evidence from China. In AMBIO: A Journal of the Human Environment, 40 (1): 78-87.

[18]. Royal Swedish Academy of Sciences.http://www.bioone.org/doi/full/10.1007/s13280-010-0093-5 